\title{
The Syrian Students in the Classes of Social Studies Teachers from Their Perspective
}

\author{
Türkan ÇELİK
}

\begin{abstract}
The aim of the study is to determine the problems experienced by the Social Studies teachers teaching in classes with Syrian students not living in the temporary refuge centre and the solution recommendations to these problems. The research is based on case study being one of the qualitative patterns. 26 Social Studies teachers in total were interviewed face to face. The data were analysed with the content analysis method. Five themes regarding the problems and five themes regarding the solutions of these problems were developed at the end of the study. The mostly emphasized findings in the themes concerning the problems that the Social Studies teachers experienced were problems such as not knowing Turkish, indifference to the class and failure, not being able to familiarize with the topics of the course, wavering between Arabic culture and Turkish culture and not being able to feel that they belong in the place they live/ non-assimilation. As for the problems that the Social Studies teachers experience, the solution recommendations were; providing adaptation training, bringing in the feeling of embracing where one lives, civic education, peer support, enriching the educational process, giving social support to families, showing empathy towards students and everyone to be patient within this process. There were also suggestions for new researches based on the results of this study.
\end{abstract}

Keywords: Social Studies teachers, Syrian students, teacher opinion, Social Studies lesson.

\footnotetext{
* Orcid ID: http://orcid.org/0000-0001-8380-9419, Assist. Prof. Dr., Kilis 7 Aralık University, Muallim Rifat Faculty of Education, Department of Turkish Language and Social Sciences, turkancelik@kilis.edu.tr
} 


\section{INTRODUCTION}

The 21st Century, in which the globalization continues at full speed, has brought about conflicts in the cultural, economic and political fields. The conflicts, sometimes, lead to great wars and miseries and thus causes other countries of the world to be affected as well. The Arab Spring, emerged and spread in the Middle East in particular in the last 10 years, is the most recent and vivid example. The political movement, commenced in Tunisia in 2011 under the title "Jasmine Revolution" and referred to as the "Arab Spring" to make it sound sympathetic as it kept penetrating other countries like Egypt and Syria, led to great sufferings, deaths, atrocities and tragedies. The most recent acts of the atrocity were hosted by Syria in March 2011. The movement in Syria resulted in compulsory mass migrations. Migration is defined as the movement of people from one place to another to live there temporarily or permanently due to several reasons (Hagen-Zanker, 2008). In the course of events in Syria, people migrated to various countries, from Europe to the US; however, the largest waves of migration headed Turkey (Bostancl, 2017). Through these waves of migration, 3.646,889 people arrived in Turkey by 2019, most of whom were children (Ministry of Interior Directorate General of Migration Management [DGMM], 2019).

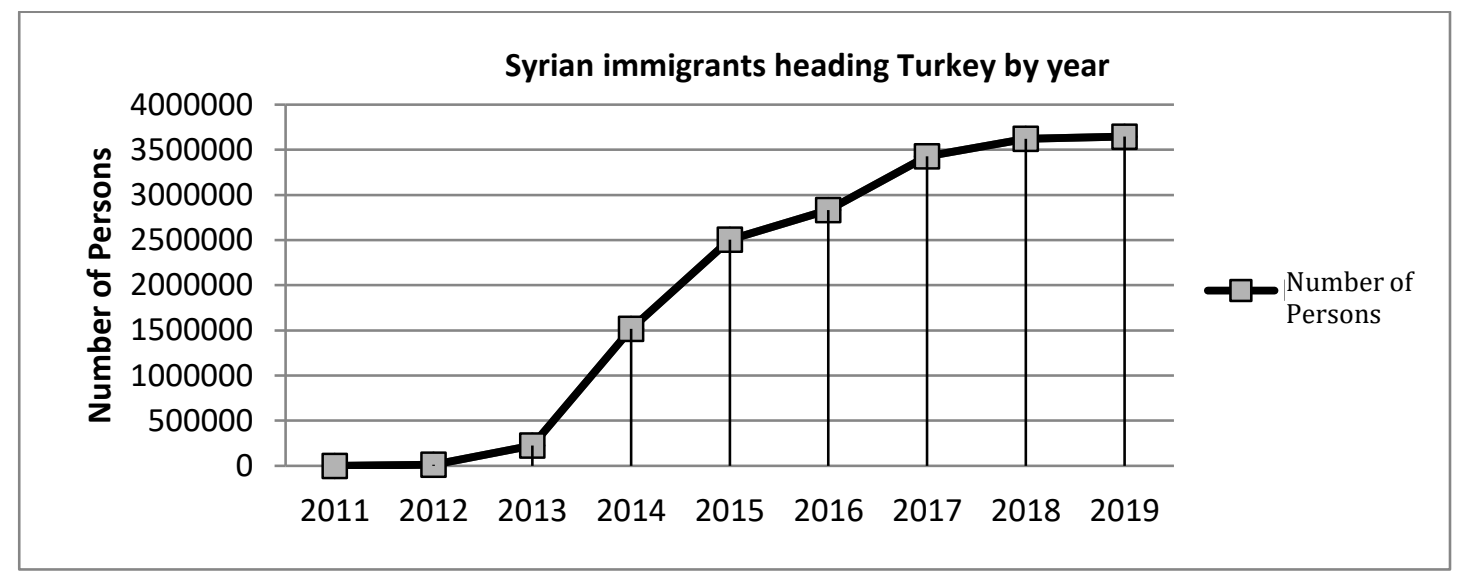

Figure 1. Number of Syrians in Turkey (DGMM, 2019)

Kids, whose lives, emotional health and education were put in danger in the course of wars and migration, were forced to pay the highest price (UNICEF Office of Research, 2019). The most vulnerable group, kids need much more attention, support and protection when they leave their own country to move to another (Crépeau, 2013). Families' falling apart, rape, kidnapping, human trafficking, diseases, malnutrition and being deprived of education are among the problems that families with children may face even during their journey (Boyden, Berry, Feeny, \& Hart, 2002; Tollefson, 1989, as cited in Adams and Kirova, 2006). On the other hand, kids also may have to undertake some adult roles and become juvenile soldiers, child brides or do housework (Harunoğulları, 2016). When they settle down in the new county, they may be subjected 
to marginalization, exclusion, prevention from accessing to social services, face problems related to citizenship and identity, economic uncertainties of parents, and social and cultural confusion (UNICEF Office of Research, 2019). However, Article 22 of the UN Convention on the Rights of the Child, where Turkey is a party, dictates that states parties shall take all necessary measures to ensure that all children, whether refugees or asylum seekers, on their territories enjoy all the rights set forth in the Convention. As stipulated in the Child Protection Law No. 5395 in Turkey, "every child is entitled to protection regardless of their nationality", which means Turkey should show the required sensitivity for all children without any exceptions (Bilgi University Children's Studies Unit [ÇoÇa], 2015, p. 2). Migrated Syrian kids may have troubles in being integrated into the education system in the host countries. For instance, they fall out of the scope of the education system due to some reasons including social and cultural isolation, tiring and hazardous jobs, extreme poverty, poor health conditions and language barrier (Rossi, 2008). In addition, the fact that people from different cultures have to live together after immigration causes certain problems such as disharmony and conflict to emerge in between immigrants and those who are subjected to influx of immigrants (Aksoy, 2012). Schools are the primary places where Syrian refugee children get to learn how to socialize and co-exist with people from different cultures. Schools, where children improve physically, cognitively and socially, learn social rules and, especially the refugee children, have the opportunity to be included in the society, are of utmost importance (Holloway and Valentine, 2000; Frater-Mathieson, 2004). Circular Law No. 2014/21 in Turkey offers the opportunity to officially registered Syrian children to receive education at schools dependent on the Ministry of National Education or Temporary Education Centers (TECs), which are established for Syrians. This law allowed Syrian children in Turkey to officially enroll in the TECs or state schools they currently attend (ÇOÇA, 2015). In addition, domestic and foreign institutions cooperate to ensure that Syrian students are able to easily benefit from all education opportunities. According to UNICEF Office of Research (2019) data, institutions such as European Civil Protection and Humanitarian Aid Operations department, Ministry of Family, Labor and Social Services (MoFLSS), Ministry of National Education (MoNE), Disaster and Emergency Management Authority (AFAD) in cooperation with the Turkish Red Crescent aim to improve school attendance of Syrian students and increase their schooling rate by decreasing dropouts. In addition to these institutions, the Ministry of Family, Labor and Social Services acts in cooperation with the Ministry of National Education to improve child protection services for psychological, physical, and cognitive development of children. Moreover, teachers are offered training to ensure all disadvantageous groups receive an inclusive education. Along with a lot of social support provided, the importance attached to teacher training for a healthy integration of Syrian kids to society and education system is striking. It is believed that teachers, who strive to help many different students in the class, have a key role in this process and thus their problems need to be heard. 


\section{Syrian Students Receiving Education Outside the Temporary Refuge Centers and Their Social Studies Teachers}

Events happening all around the world in recent years affected Turkey as well as many other countries. Most of the people who migrated in masses upon the outbreak of the civil war in Syria in particular headed Turkey. As is seen in Figure 2, majority of the Syrian immigrants in Turkey live outside the temporary refuge centers (DGMM, 2019).

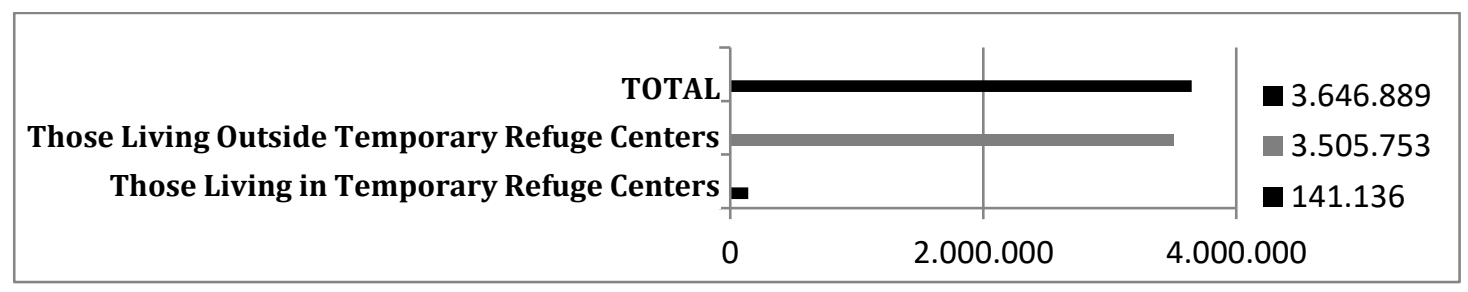

Figure 2. Syrians living outside and in the temporary refuge centers in Turkey (DGMM, 2019)

The Ministry of Education has offered two models for the education of Syrian children living disconnectedly, with most living outside the camps (Emin, 2016). First of them is the Temporary Education Centers, referred to as TECs, offering pre-school and middleschool education in Arabic to the Syrian children and youth within and outside the camps, based on the curriculum in Syria (Kağnıcl, 2017). In this model, Syrian teachers teach the classes voluntarily and their salary is paid under the project carried out by UNICEF and PTT (Turkish Post) (Amaç and Yaşar, 2017; Kağnıcl, 2017; Emin, 2016). However, as their name suggests, TECs offer temporary service and are planned to be shut down gradually (Amaç and Yaşar, 2017). Second of these efforts, aiming to prevent Syrian children from falling behind their education, is the education provided by the Ministry of National Education at Turkish schools. In order to ensure that Syrian children who are enrolled in Turkish schools are able to adapt to the Turkish society and education system more easily, they are offered education in Turkey based on the curriculum followed at state schools (Emin, 2016).

Children, especially those who pay the highest price for the wars and migrations, need to continue education for adaptation to social life. Education of migrants should be of the highest priority so that they can attain a proper social and cultural integration (Kihtir, 2003; Söhn and Özcan, 2006). However, when refugee students who are spread across the country are decided to receive education at state schools, some problems emerge from the point of teachers. For instance, the discrepancy between the language they speak at home and the medium of instruction makes it necessary for the immigrant children to have multilingual literacy skills (Saracaloğlu, 2014). Not only the refugee children but also their teachers need to exert additional effort in this process in which emerge problems affecting both. The refugee children come from different cultural backgrounds and lack a common tongue, the schools become obliged to fulfill the 
educational needs of students from different ethnic origins and backgrounds, which affects both the students and the teachers in the adaptation process. Teachers have to deal with particular challenges and requirements coming with refugee children (Rah, Choi and Nguyen, 2009) and do not know how to communicate with and treat them (Karaca and Doğan, 2014). Roxas (2010) states that, in general, teachers do not have the knowledge and experience regarding how to work with refugee children from different backgrounds. He also mentions that school managements expect academic achievement of teachers but ignore such problems and leave teachers to their own devices in dealing with them. There is a limited number of studies focusing on how teachers react when there are refugee or asylum seeker students in their class (Arnot, Pinson, Candappa, 2009). Some of the studies found in the literature (Aykırı, 2017; Biçer and Kılıç, 2017; Bulut, Kanat Sosyal and Gülçiçek, 2018; Erdem, 2017; Keskinkılıç Kara and Şentürk Tüysüzer, 2017; Kiremit, Akpınar and Tüfekçi Akcan, 2018; Miller, 2009; Özer, Komsuoğlu and Ateşok, 2016; Şahin and Doğan, 2018; Topkaya and Akdağ, 2016; Yaşar and Amaç, 2018) deal with the problems teachers have in addition to different crucial partners in education. In their study, Özer et al. (2016) emphasize that education needs to be considered a "right" rather than a public service offered to citizens and the education policies for the Syrian refugee children must adopt an individual-oriented perspective instead of a problem-oriented and short-term perspective. One of the greatest challenges teachers face is the language barrier (Biçer, \& Kılıç, 2017; Bulut et al., 2018; Erdem, 2017; İlgar, Doğan, \& Yıldırım, 2017; Keskinkılıç Kara et al., 2017; Kiremit, et al., 2018; Miller, 2009; Sarıtaş et al., 2016; Şahin, \& Doğan, 2018; Yaşar, \& Amaç, 2018). So much so that, teachers have to teach children, whose language they cannot speak and whose literacy is not sufficient even in their own mother tongue, complex topics in a new language. Thus, language difference not only hampers a sufficient communication but also affects children's socialization, class comprehension, and academic and social success at school. Therefore, an effective management and education policy are of great importance with regard to immigrants' living conditions and intercountry communication (Ministry of Interior Directorate General of Migration Management, 2013). Apart from the language problem, some studies (Biçer, \& Kılıç, 2017; Erdem, 2017; Şahin, \& Doğan, 2018) draw attention to the fact that the content of education and the class materials such as text books used in teaching do not fit the children's level, which may lead to problems such as boredom and failure to adapt the class, academic failure, discipline and adaptation issues, which is also supported by the studies touching upon the fact that Syrian students have behavioral and adaptation problems with the people around and friends due to cultural differences (Keskinkılıç Kara et al., 2017; Kiremit et al., 2018; Sarıtaş et al., 2016; Şahin, \& Doğan, 2018). Teachers, who have the main responsibility in the education process of Syrian students at Turkish schools, need to create the proper educational environment and have the required skills to use teaching materials fit the course content. This way they can ensure active participation of Syrian children who are different from each other in many aspects in the education process. However, some studies (Aykırı, 2017; Erdem, 2017; Yaşar, \& 
Amaç, 2018) revealed that teachers consider themselves insufficient, have not received any trainings and expect to be trained pertaining thereto. This study rather focuses on the problems experienced by Social Studies teachers with refugee students and solution suggestions. However, first we need to look at the specific goals of the Social Studies class.

\section{"SPECIFIC GOALS OF THE SOCIAL STUDIES CURRICULUM"}

According to the General Goals and Basic Principles of the Turkish National Education as set out in the National Education Basic Law No. 1739, Social Studies Curriculum aims to raise students who

1. As the citizens of the Republic of Turkey, love their country and nation, know and exercise their rights, fulfill their duties, and have national consciousness,

2. Are eager to sustain democratic, secular, national and contemporary values, acknowledging the place of Atatürk's principles and reforms in the social, cultural and economic development of the Republic of Turkey,

3. Know that provisions of law are binding for everyone and all persons and institutions are equal before the laws,

4. Understand the basic elements and processes constituting the Turkish culture and history and acknowledge that the cultural heritage, which ensures the formation of national consciousness, needs to be protected and improved,

5. Explain the interaction between humans and environment knowing the environment they live in and general geographical features of the earth and improve their spatial perception skills,

6. Are aware of the finiteness of natural environment and resources, endeavor to protect natural resources with an environmental awareness and have a notion of environmental sustainability,

7. Have critical thinking skills as individuals who know how to reach accurate and reliable information,

8. Understand basic economic terms and the role of national economy in the development and international economic relations,

9. Believe that working is important in social life and every profession is necessary and estimable,

10. Identify the similarities and differences between people, objects, events and facts by questioning the historical evidence from different eras and places, and perceive change and continuity,

11. Being aware of the development process of science and technology and their effects on the social life, use information and communication technologies,

12. Taking science as basis, observe scientific ethics in reaching, using and producing information,

13. Are able to use basic communication skills and basic concepts and methods of social sciences in order to arrange social relationships and address problems they encounter,

14. Believe in the importance of participation, express their opinions for solving social problems,

15. Understanding the history behind the concepts of human rights, national sovereignty, democracy, secularism, and republic and their effects on modern Turkey, design their lives in accordance with democratic rules,

16. Adopting national, moral and universal values, know the importance of being and how to become a virtuous human being,

17. Sensitive about issues concerning their country and the world,

18. Are aware of their physical and emotional traits, interests, desires and talents as free individuals."(Ministry of National Education, 2018, p. 8)

There are quite different problems waiting for social studies teachers. As can be seen in the special goals of the social studies class, it is local and national so the problems emerging for the Syrian children and what teachers think about the respective teaching process are of great importance. 


\section{Aim of the Study}

This study aims to identify the problems the Social Studies teachers who work at classes attended by Syrian students living outside temporary refuge centers have and their solution proposals to such problems. In this regard, the following questions were investigated.

- What are the problems encountered by Social Studies teachers in the teaching process who work at classes attended by Syrian students?

What solutions do Social Studies teachers, who work at classes attended by Syrian students, propose to the problems they encounter in the teaching process?

\section{METHOD}

In this study, the social studies teachers of the Syrian children who are enrolled in schools in Gaziantep were interviewed with. The study was designed qualitatively in order to deal with the teachers' opinions. Qualitative research is a method focusing on human experience and trying to understand how people build up their worlds and the meaning they attribute to their experiences.

\section{Design of the Study}

This study is conducted based on the case study design. Case study is a qualitative study design in which researchers conduct in-depth analyses on one or more cases and put forth systematic and ordered patterns. Case studies enable examining more than one case in detail (Yıldırım, \& Şimşek, 2013) made it easier to examine cases associated with Syrian students that the teachers experience. The researchers made use of the advantages of case study during the face-to-face interviews. Case studies offer the opportunity to use techniques such as observation, interview, audio recording and come up with a detailed description of the case at hand (Creswell, 2015). Thus, since the subject matter of the study requires going into detail in general

in the data collection process, qualitative research method is adopted. The researcher took part in the data collection process in person and had the participants confirm some of the answers to make sure what they meant was exactly understood.

\section{Study Group}

The study group consists of 26 social studies teachers based in Gaziantep who have at least one Syrian student in their class. After each individual and face-to-face meeting with teachers, other teachers who have Syrian students in their class were contacted based on the interviewees' suggestion. In this regard, the study used snowball sampling. Snowball sampling is a method in which information regarding who to interview next accumulates adding to the existing ones (Patton, 2014). In this study, 16 social studies teachers were asked if they know anyone who might have knowledge on the subject, and they can suggest for an interview. Data collection from participants was terminated once 
the data started to get repetitive. Teachers who participated in the study have been teaching social studies for four years and more. Participants consist of 10 women and 16 men. Data obtained throughout the study was presented in the results section. Participants whose statements were provided as examples are referred to with symbolic codes such as T-1, T-2, and so forth.

\section{Data Collection and Data Collection Tool}

Interview method was adopted in the data collection process of the study. Ylldırım and Şimşek (2013) state that interview is different from situations in daily life in which people sometimes do not hear or even misunderstand each other and profoundness is absent. A qualified interview does not contain errors arising from insufficient listening and biases. In this study, data was collected via face-to-face interviews made with teachers. Patton (2014) highlights that interviewing is a method used to reveal situations that cannot be directly observed on humans. He also states that interview aims to understand the individual's point of view by way of penetrating his/her inner world. The researcher played a great part in conducting interviews in smoothly. A social studies teacher based in Gaziantep, he managed to find and interview teachers having Syrian students in the data collection. For the interviews, the researcher conducted a literature search and created a semi-structured interview form beforehand. The form took its final shape based on the opinions of three consulted experts. Creating the semistructured interview form, the researcher tried to reach teachers working at the relevant schools enrolling Syrian students. The interviews were conducted on a volunteer basis. The researcher, first, interviewed four social studies teachers who work at his school. Then, based on suggestions, other social studies teachers were found. Although the researcher wanted to use an audio recorder, the interviews were recorded in written form since the participants were worried and felt uneasy about their voices' being stored. Data was transferred to the word processing software and took approximately ten pages in digital environment.

\section{Data analysis}

The data obtained in this study about Syrian students from the participants was analyzed via the method of content analysis. Content analysis aims to reach concepts and relationships that are capable of explaining the data at hand. In descriptive analysis, data is summarized and interpreted whereas analyzed in more detail in content analysis. Concepts and themes that do not come to the forefront in descriptive analysis get revealed in this method. Content analysis is also defined as "any qualitative data reduction and sense-making effort that takes a volume of qualitative material and attempts to identify core consistencies and meanings" (Patton, 2014, p. 453). The data obtained in this study was read word by word, line by line and then put into a pattern based on the meaning relationships amongst them. These patterns enabled reaching the themes and sub-themes. By this way, the data was analyzed inductively starting from the smallest meaningful unit proceeding to the bigger ones. 


\section{Validity and Reliability of the Study}

Interview data was put in writing and approved by the participants to ensure cogency (internal validity) for the sake of validity. In order to be assured about the internal validity of the research, two experts were consulted in identifying the extent to which the themes and sub-themes, created to measure whether or not the study is reliable, were analyzed similarly. Analyses performed by different experts were also considered. The formulation proposed by Miles and Huberman (2015) [Reliability=Agreement/(Agreement+Disagreement)] was utilized in the calculation of the agreement percentage of coding between analyses. The respective percentage between the coding made by two experts was found to be $92 \%$. In addition, the interview data obtained within the scope of the study, coding and theming efforts made in the course of analysis and field notes were kept to be submitted for confirmation if required to ensure confirmability (external reliability).

\section{FINDINGS}

Data obtained from the social studies teachers' opinions about the Syrian students in their classes was analyzed through content analysis. Two dimensions emerged at the end of analyses, namely, the problems encountered by the social studies teachers and the solutions proposed by the social studies teachers with respect to Syrian students. There are five themes under dimensions of questions and solution proposals and depending on these dimensions, sub-dimensions emerged. First, the themes that emerged in the problems dimension were addressed.

\section{What Are the Problems Encountered by Social Studies Teachers Who Teach at Classes Attended by Syrian Students?}

This is the dimension which consists of five themes identified based on the social studies teachers' accounts regarding the problems they have about the Syrian students and the sub-themes depending on them. The themes are the language-related problems with Syrian students, academic problems with Syrian students, problems with Syrian students on national matters, cultural problems with Syrian students and problems concerning Syrian students' adaptation to environment. The most prominent theme in the social studies teachers' accounts pertains to language and communication problems with Syrian students. All of the teachers who participated in the study spoke of this issue. 


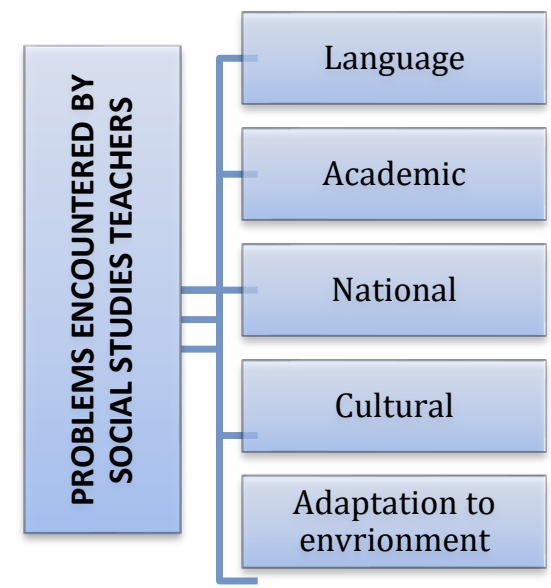

Figure 4. Problems encountered by social studies teachers

\section{THEME 1: Language-Related Problems with Syrian Students}

Seven sub-themes emerged within the scope of the language-related problems the social studies teachers have with Syrian students. These sub-themes are about the problems associated with Syrian students' insufficient vocabulary and conceptual repertoire, starting school without knowing Turkish, the difference between the alphabets, and, in general, the students' inability to speak Turkish.

Table 1.

Language-Related Problems with Syrian Students

\begin{tabular}{|c|c|c|}
\hline Theme & Sub-theme & $\mathrm{F}$ \\
\hline \multirow{7}{*}{$\begin{array}{l}\text { Language-related problems with Syrian } \\
\text { Students (26) }\end{array}$} & Not knowing Turkish & 6 \\
\hline & Language-related failure & 5 \\
\hline & $\begin{array}{l}\text { Insufficient vocabulary and } \\
\text { conceptual repertoire }\end{array}$ & 5 \\
\hline & $\begin{array}{l}\text { Starting school without knowing } \\
\text { Turkish }\end{array}$ & 4 \\
\hline & $\begin{array}{l}\text { Language-associated } \\
\text { noncommunication }\end{array}$ & 3 \\
\hline & Resistance to learn Turkish & 2 \\
\hline & Difference between the alphabets & 1 \\
\hline
\end{tabular}


"They do not understand certain concepts due to insufficient vocabulary. I observe that they have hardship in learning since there are a lot of words and concepts used in social studies class that they do not encounter in daily life." (T-6)

"I feel that the students have trouble in understanding me when I teach the class. I exert effort to explain the concepts, which interrupts the lecture's pace and causes the Turkish students to get bored." (T-15).

"First of all, language is the biggest problem. The children have trouble in understanding what is being told. Some of them do not even understand at all. In addition, they have difficulty and fall behind in writing as well." (T-14).

"We have language-related problems with Syrian students in classes. They do not understand what we teach since they do not know Turkish, which causes disciplinary problems to arise in our classes." (T-5)

"What arouses my attention about Syrian students is the behavioral difference between those who start school before learning Turkish and those who can speak Turkish enough to explain themselves. Students who cannot speak Turkish may be quite introvert, not open to communication or may overreact and even exhibit violent behaviors when they have a problem with their friends." (T-7)

"I cannot teach the 5th grade students in particular. They have been enrolled in school for 3-5 months but do not know Turkish at all. I cannot understand them either. There is one or two who can speak Turkish. We call and have them translate." (T-8)

"Syrian students do not speak Turkish at home and they form groups at schools and speak Arabic all the time." (T-19)

"The difference between the alphabets and the fact that Syrian kids lack the knowledge and skills required by the Turkish language prevent them from learning social studies at the desired level." (T-4)

\section{THEME 2: Academic Problems with Syrian Students}

This theme is about the academic problems encountered with the refugee children. The academic problems emerging under this theme include the sub-themes of indifference to and failure in the class and difficulty in adaptation to the class, making things difficult for the teacher, and timidity. In this regard, the most prominent problem is "indifference to and failure in the class" as can be seen in Table 2 below.

Table 2.

Academic problems with Syrian students (25)

\begin{tabular}{|c|c|c|}
\hline Theme & Sub-theme & $f$ \\
\hline Academic problems with & Indifference to and failure in the class & 11 \\
\hline Syrian students (25) & Making things difficult for the teacher & 7 \\
\hline
\end{tabular}


Difficulty in adaptation to the class 6

Timidity 1

"To talk about my own students, they are here due to reasons beyond their control. Not because they love us, the school or the class but because they feel they have to. Thus, they are indifferent to the social studies as they are to the other courses." (T-2)

"In general, their class participation level is low. In case of a situation that is unknown and bizarre to them, they try to grasp it in silence and a quiet manner." (T-10)

"The fact that they became distanced from school in the course of migration and could not get accustomed to the school culture has reflections on their relationship with the class." $(T-4)$

"Since they do not have a command of topics that were covered in the past years, they fail in establishing correlations among subjects." (T-9)

"The number of students per class at our school is above the average. To top it off, presence of Syrian kids increases teachers' duties and responsibilities which makes it impossible to reach out to the students." (T-4)

"I observe that students are timid in class participation. The kid has trouble in expressing him/herself. S/he has been observed to behave shy when playing with friends and usually fail to make friends." (T-11)

\section{THEME 3. Problems with Syrian Students on National Matters}

The social studies teachers stated that they have problems with Syrian students when they teach national matters. ${ }^{1}$ Refugee students exhibit specific attitudes and manners toward the topics covered in the social studies class that fall under this theme. Such attitudes and manners include finding these topics none of their concern, not caring about them, extreme nationalism, misunderstanding and being biased. As is seen in Table 3, the most prevalent view is that they find the topics covered in the social studies class none of their concern.

Table 3.

Problems with Syrian students on national matters

\begin{tabular}{lll}
\hline Theme & Sub-theme & $\mathrm{f}$ \\
\hline Problems with Syrian students on national matters & $\begin{array}{l}\text { Finding such matters } \\
\text { none of their concern }\end{array}$ & 10
\end{tabular}

\footnotetext{
1 The problems under this theme can be listed as the matters concerning the values and traditions of the state of the Republic of Turkey, Turkish history, Turkish geography, national holidays, Turkish customs and traditions, the Turkish War of Independence, Mustafa Kemal Atatürk, Turkish flag, and so forth.
} 
Not caring about such 4 matters

Extreme nationalism 3

Misunderstanding 2

Biases

"A Syrian student of mine drew our Turkish flag on their notebook small. However, their flag was drawn big. In their world, we are not of importance (as I said earlier, due to reasons beyond their control)" (T-2)

"The map displaying the battle fronts covered by the culture and heritage unit also includes the Syrian front, which creates the impression that Turks attempted to occupy Syria." (T-1)

"They are indifferent to the topics covering Atatürk and the years of Turkish national struggle because they are not related to their past. They are indifferent to nationalism. I have trouble in teaching the topics of identity, the national struggle, and Atatürk. Although I talk about Atatürk's life, there is no feedback pertaining thereto." (T-2)

"We had hardship in all topics on the Turkish national struggle." (T-3)

"They do not understand when we cover the topics of 'Our Cultural Elements' in the 5th grade and 'Turks with Epics and Inscriptions' in the 6th grade and fail." (T-16)

"We have problems in the culture and heritage topic at the 5th grade, in the Turks on the Silk Road unit at the 6th grade, and the journey to the Turkish history unit at the 7th grade." (T-20)

"Especially, I sometimes feel uneasy when I speak of Arab's betrayal toward the Ottoman Empire at Syria-Palestine front during the World War I in the History of Turkish Revolution class. I choose my words carefully. Because our class contains ideological elements." (T-20)

\section{THEME 4: Cultural Problems with Syrian Students}

Culture is the entirety of a society's material and nonmaterial building blocks. Each culture has its own artistic style, beliefs, manners and customs, mentality and behaviors. Thus, culture is the identity of society and influential in the establishment of the social order as well the sense of solidarity and unity (URL-1, 2019). In this study, students' wavering between the Arab culture and the Turkish culture, Turkish culture's strangeness to them and the difficulty they have in learning local norms come into prominence within the scope of the cultural problems theme. As can be seen in Table 4 below, teachers mostly highlighted the problem of wavering between two cultures experienced by the refugee students. 
Table 4.

Problems with Syrian students on cultural matters.

\begin{tabular}{llr}
\hline Theme & Sub-theme & $\mathrm{f}$ \\
\hline & Wavering between the Arab culture and the & 8 \\
Problems with Syrian students on & Turkish culture \\
cultural matters (19) & Being a stranger to the Turkish culture & 6 \\
& The difficulty in learning local norms & 5 \\
\hline
\end{tabular}

Kids waver between the Arab culture and the Turkish culture since their families do not adopt the Turkish culture (T-1).

"Cultural difference bring brings about discord. The fact that they are introverted and silent in the classroom causes them to get alienated. Syrian Turkmens are more culturally congruent and do not feel out of place, so they do not have orientation problems. Those of Arabic origin, however, have more troubles." (T-20)

"They have troubles in repeating the topics that are strange to our culture and they have just learnt in class." (T-2)

"Topics are also strange to them... They do not exert effort since the topics are irrelevant to their culture." (T-21)

"The fact that they are from different cultures causes the students to have great difficulties in learning the local norms that are required by the social studies class." (T-4)

"Teaching the features of the pre-Islamic age of ignorance may have a negative influence on them." (T-14)

\section{THEME 5: Problems Concerning Syrian Students' Adaptation to Environment}

The concept of environment here refers to where a person lives, shelters him/herself, work, receive education, communicate with people, live with other people, make new friends, and get to know new cultural and social norms. Based on the teachers' accounts, the Syrian students have been found to face problems including not feeling belong to and failing to embrace Turkey, and they do not manage to adapt to the environment no matter how they try, under the theme of adaptation to environment. The prominence of the students' lack of sense of belonging and failure to adopt where they live as home in the teachers' observation is striking. 
Table 5.

Problems Concerning Syrian Students' Adaptation to Environment

\begin{tabular}{llc}
\hline Theme & Sub-theme & $\mathrm{f}$ \\
\hline Problems encountered with respect to Syrian & Lack of sense of belonging & 12 \\
students' adaptation to their environment (14) & /Failure to adopt as home & \\
\cline { 1 - 1 } & Failure to adapt & 2
\end{tabular}

"It gets harder for the kid to develop a sense of belonging" (T-1).

"The fact that Syrian students consider their stay in Turkey not permanent and do not develop a sense of belonging leads to problems with adapting to school and disobedience to school rules (e.g., getting in a fight)" (T-15).

"Syrian students have difficulty in making friends. They are shy and timid in their manners. They have adaptation problems. They always observe their surroundings; they are aware of that everything is strange to them." (T-10)

\section{What Are the Solutions Proposed by the Social Studies Teachers to the Problems They Encounter?}

Five themes in total emerged in the second dimension of the study, the solutions proposed by the social studies teachers to the problems they encounter with Syrian students, which can be listed as providing the Syrian students with cohesion training, providing the Syrian students with national consciousness education, strengthening peer relationships with the Syrian students, conducting academic studies for Syrian students and providing social support for the Syrian students. The most prominent theme is the one where the solution "Providing the Syrian students with cohesion training" was proposed. Depending on the themes that emerged, sub-themes and participants' accounts pertaining thereto are also provided. First, the most emphasized theme about the encountered problems is addressed.

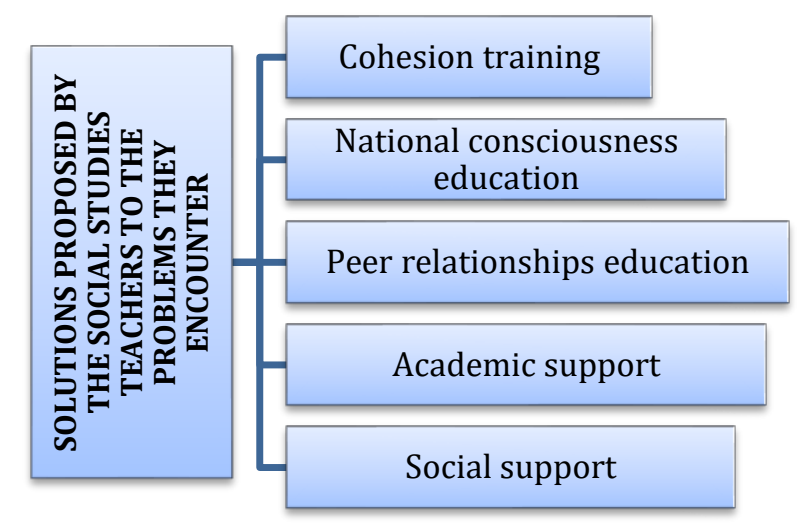

Figure 5. Solutions proposed by the social studies teachers to the problems they encounter 


\section{THEME 1: Proposal of Cohesion Training for the Syrian Students}

Five sub-themes emerged in the theme concerning the "cohesion training proposal", the most emphasized solution proposal to the problems encountered by the social studies teachers with the Syrian students in their class. The sub-themes in question are offering education at language centers before inclusive education, teaching language and cultural concepts before inclusive education, orientation training, orientation training for families and orientation training for teachers. The most emphasized sub-theme consisting of teachers' proposals is the one concerning the provision of "education at language centers before inclusive education"

Table 6.

Cohesion training for the Syrian students

\begin{tabular}{llc}
\hline Theme & Sub-theme & $\mathrm{f}$ \\
\hline $\begin{array}{l}\text { Proposal of } \\
\text { providing } \\
\text { orientation }\end{array}$ & $\begin{array}{l}\text { Providing education at language centers before inclusive } \\
\text { education }\end{array}$ & 12 \\
sessions for the & $\begin{array}{l}\text { Teaching the language and cultural concepts before } \\
\text { inclusive education }\end{array}$ & 7 \\
$(24)$ & $\begin{array}{l}\text { Orientation training } \\
\text { Providing families with orientation training }\end{array}$ & 3 \\
& Providing teachers with orientation training & 1 \\
\hline
\end{tabular}

"They should know sending their children to school is not enough to fulfill their duties as parents. They need to cooperate with the school to ensure that these kids have a future" (T1)

"I am absolutely opposed to schooling these kids right away at Turkish schools. The kid does not know Turkish. There is no chance of success in this way. Those kids need to learn Turkish first. In my opinion, those kids should be gathered somewhere and thought Turkish, then they can get enrolled to these schools." (T-8)

"First of all, Syrian students' Turkish skills (reading, writing, speaking) must be improved." (T-14).

"Before enrolling Syrian students, they can be furnished with knowledge of Turkish language, history and culture at public education centers or separate classrooms allocated in the schools" (T-5).

"I believe that such problems may be eliminated by way of providing the Syrian students with education on our country's national values, geography, and culture in addition to teaching how to read and write in Turkish" (T-6). 
"Syrian students should be granted orientation training through the agency of students chosen by school administration and school counselors" (T-20).

"They should be subjected to orientation to adapt to our schools. The teachers who teach to Syrian students should be offered training" (T-5).

"Teachers can get in contact with their parents. There are courses opened by the state to this end, but it is not enough. Only specific teachers were invited to these courses. Teachers should first be offered courses about the Syrian students" (T-9).

\section{THEME 2: Proposal of Cohesion Training for the Syrian Students}

Another theme consisting of the proposals of the social studies teachers is the one with the "providing the Syrian students with national consciousness education" solution. In this regard, the following three sub-themes emerged: a sense of ownership should be earned, civic education should be offered, and a perception of homeland should be created. As can be seen in Table 2, earning the Syrian students a sense of ownership for the values of the place and environment they live in is the theme which was emphasized most.

Table 7.

National consciousness education for the Syrian students

\begin{tabular}{llc}
\hline Theme & Sub-theme & $\mathrm{f}$ \\
\hline National consciousness & A sense of ownership should be earned & 3 \\
education for the Syrian & Civic education & 2 \\
students (7) & Perception of homeland & 2 \\
\hline
\end{tabular}

I believe it would be of help if they learn civic duties, rights and responsibilities in order to be better citizens in our country. Because these kids plan to live in this country for many years to come (T-6).

Civic awareness should be raised among the kids. Because these people intend to stay in our country permanently. (T-20).

First, it must be ensured that they love and embrace their social environment, school and class (T-2).

Students' sense of belonging to and embracing our country need to be improved (T-15).

The families should understand that the Republic of Turkey is not a country to earn money, but a homeland the national culture of which must be protected (T-1).

Furnishing students with national, spiritual values (T-15)

THEME 3: Proposal to Improve Syrian Students' Relationship with Peers

During the interviews, the social studies teachers mentioned that sometimes problems arise due to the refugee students' peer relationships. The analysis of these accounts 
revealed three sub-themes under the proposal "Peer relationship education for Syrian students", which are improving relationship with friends, providing peer support and offering students cohesion training within the scope of social studies.

Table 8.

Peer relationships with the Syrian students

\begin{tabular}{llc}
\hline Theme & Sub-theme & $\mathrm{f}$ \\
\hline & Peer support & 3 \\
Peer relationships with the & Improving relationships with friends & 2 \\
Syrian students (7) & $\begin{array}{l}\text { Cohesion training for the students within the } \\
\text { scope of social studies class }\end{array}$ & \\
\hline
\end{tabular}

"They should establish better relationships with their friends" (T-2).

"An awareness should be raised among students that the deeds like fight and violence are wrong" (T-15).

"Peer education may enable minimizing the problems in this process" (T-20).

"Our priority must be engaging these students in school. We can do it better with the support of their classmates" (T-21).

"The social studies class aims to create a mosaic society that has adopted the cultural values. Thus, an adaptation training can be offered within the scope of the social studies class for the integration of the refugee students to society." (T-4)

"Their adaptation must be ensured in terms of school and social rules" (T-15).

\section{THEME 2: Proposal of Academic Studies for Syrian Students}

The theme "Academic studies for Syrian students" was reached based on the solutions proposed by the social studies teachers regarding the Syrian refugee students. This theme contained four sub-themes including enriching the educational process, rendering books more activity-based, starting the students from one grade lower and bringing those kids to the forefront. As can be seen in Table 4 below, the theme on which the most emphasis is put is "enriching the educational process".

Table 9.

Academic studies for Syrian students

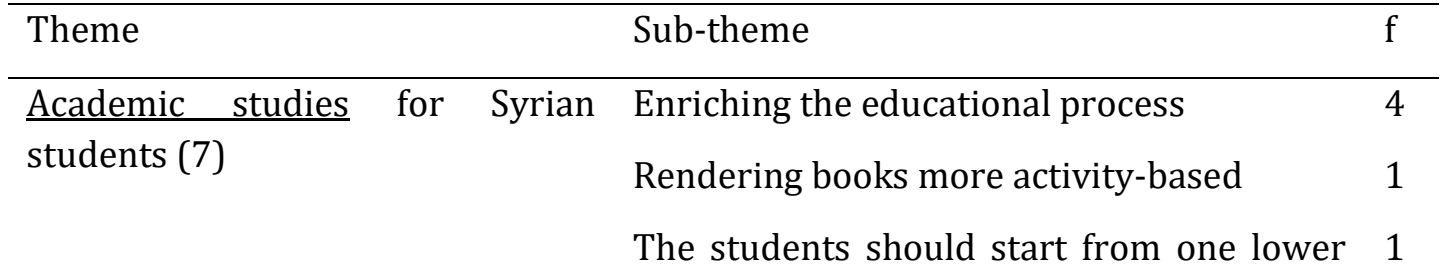


grade

Bringing them to the forefront

"Social studies textbooks should be prepared with simpler content and teachers should use audiovisual materials in addition to textbooks" (T-22).

"Not only auditory but also visual learning should be ensured increasing the opportunities (technological) at school" (T-24).

"Social studies textbooks should be simplified to a level that the children can understand and include more activities" (T-2).

"I believe Syrian students should start school from lower grades" (T-12).

"Syrian students must be assigned duties and responsibilities to bring them to the forefront and promote self-confidence so that they can adapt to the school and the environment" (T20).

\section{THEME 5: Proposal of Social Support for Syrian Students}

The theme "Social support for Syrian students" was reached based on the solutions proposed by the social studies teachers regarding the Syrian refugee students in their class. Teachers recommend all the citizens, with educators in particular, provide social support to families, empathize with them, and be patient.

Table 10.

Social support for Syrian students

\begin{tabular}{llc}
\hline Theme & Sub-theme & $\mathrm{f}$ \\
\hline Social support for Syrian students (3) & Social support to families & 1 \\
& Empathizing with students & 1 \\
& Patience & 1 \\
\hline
\end{tabular}

"According to me, the most significant solution that can be implemented for these students is feeling sympathy toward their culture and offering classes accompanied by a teacher" (T-11).

"Syrian students' adaptation process to Turkey requires at least three generations. We need time and patience for this" (T-13).

\section{CONCLUSION, DISCUSSION AND RECOMMENDATIONS}

The largest migration wave to Turkey in recent years has been from Syria. Some of the Syrian families live with their children outside the temporary refuge centers in this 
migration process. Children of the families living outside the temporary refuge centers continue their education at Turkish schools implementing a curriculum in Turkish. However, inclusion of Syrian students in the formal education system gave rise to some problems. Teachers have an important part in the education process and constitute the most affected group searching for solutions. Studies (Aykırı, 2017; Erdem, 2017; Keskinkılıç Kara et al., 2017; Biçer and Kılıç, 2017; Bulut et al., 2018; Kiremit et al., 2018; Şahin and Doğan, 2018; Yaşar and Amaç, 2018) highlight that teachers face various problems during this process. For example, the prominent problems identified in the study carried out by Yaşar and Amaç (2018) are language barrier, lace of family support, and lack of teachers' knowledge and skills concerning refugee students. At the end of this study, five themes concerning the problems the social studies teachers encounter with Syrian refugee students and five themes concerning the solution proposals pertaining thereto were obtained. In addition, depending on the themes about the problems and solution proposals, sub-themes were also obtained from the in-depth interviews. Problem-related themes are the language-related problems with Syrian students, academic problems with Syrian students, problems with Syrian students on national matters, cultural problems with Syrian students and problems concerning Syrian students' adaptation to environment. The most prominent theme in the social studies teachers' accounts pertains to language and communication problems with Syrian students. All of the teachers who participated in the study laid emphasis on the language problem. Seven sub-themes emerged within the scope of the language-related problems the social studies teachers have with Syrian students. These teachers stated that Syrian students have an insufficient vocabulary and conceptual repertoire, start school without knowing Turkish, and encounter problems due to the difference between the alphabets, and, in general, their inability to speak Turkish. This result matches different research findings (Miller, 2009; Sarıtaş et al., 2016; Biçer and Kılıç, 2017; Keskinkılıç Kara et al., 2017; Erdem, 2017; Bulut et al., 2018; Kiremit et al., 2018; Şahin and Doğan, 2018; Yaşar and Amaç, 2018). For instance, the findings obtained by Bulut et al. (2018) revealed that teachers implement the same curriculum for the refugee children whose mother tongue is not Turkish and the children whose mother tongue is Turkish and they do not know how to address such problems since they have not received any training on it. On the other hand, according to another study (Gün and Baldık, 2017) the refugee children stated that they are not offered sufficient opportunity to learn Turkish. Sub-themes regarding the hardship the students have in adapting to the class and such experiences make things harder for teachers. The study carried out by Erdem (2017) has similar results and point to teachers as the source of the problem. According to Erdem's findings (2017), teachers have troubles in preparing the teaching content in a way to match the refugee students' level and they need professional development. This study has a surprising finding that the involvement of students in the educational process depends on the textbook. Thus, it is believed that the students' silence and indifference when they could not participate in the class, which eventually results in academic failure, is closely associated with teachers' knowledge, skills, 
attitudes and behaviors. Another theme obtained through this study is about the "problems regarding the national matters" encountered by the social studies teachers in class. The prevalent sub-themes that emerged within the scope of the main theme are "finding the topics strange", "extreme nationalism", "misunderstandings" and "biases". One of the teachers, (T-2), said, "A Syrian student of mine drew our Turkish flag on their notebook small. However, their flag was drawn big. In their world, we are not of importance (as I said earlier, due to reasons beyond their control)," which means that teachers feel uncomfortable about refugee students' extreme nationalism. In addition, as one teacher (T-2) said, "They are indifferent to the topics covering Atatürk and the years of Turkish national struggle because they are not related to their past", problems may also arise from some topics and units and Syrian students find the content of the class strange to themselves It can be understood from the teacher account, "They do not understand when we cover the topics of 'Our Cultural Elements' in the 5th grade and 'Turks with Epics and Inscriptions' in the 6th grade, and fail" (E-16), students experience academic failure due to the said indifference. Teachers hesitation about causing a misunderstanding and prejudice when teaching some of the topics under Turkish history reflected on this account: "I sometimes feel uneasy when I speak of Arab's betrayal toward the Ottoman Empire at Syria-Palestine front during the World War I. I choose my words carefully. Because our class contains ideological elements." (T-20)". Another result of the study is the theme related to the problems encountered in cultural matters with Syrian students. Under this theme, the social studies teachers stated that students "waver between the Arab culture and the Turkish culture", "are strange to the Turkish culture" and "have difficulty in learning local norms" which are compatible with the results obtained from some other studies (Sarıtaş et al., 2016; Keskinkılıç Kara et al., 2017; Kiremit et al., 2018; Şahin and Doğan, 2018). Another theme that was reached based on social studies teachers' accounts on the problems they face with Syrian students is about adaptation to their environment. Under this theme, teachers stated that refugee students have troubles because they "do not belong to/embrace Turkey as home" and "fail to adapt to the environment no matter how they try".

Social studies teachers not only talked about the problems they encounter but also proposed solutions to these problems. Findings of this study contains five different themes emerged regarding the solution proposals which can be listed as "providing the Syrian students with cohesion training", "providing the Syrian students with national consciousness education", "strengthening peer relationships with the Syrian students", "conducting academic studies for Syrian students" and "providing social support for the Syrian students". The most prominent theme is the one where the solution "Providing the Syrian students with cohesion training" was proposed. The results obtained under the first theme in which the cohesion training solution was proposed are offering education at language centers before inclusive education, teaching language and cultural concepts before inclusive education, orientation training, orientation training for families and orientation training for teachers. The most emphasized result in this theme is the proposal to "provide language education in language centers before inclusive education." 
In another theme, teachers suggested recommended national consciousness education be granted to Syrian students. In this regard, the following results were obtained: "a sense of ownership should be earned", "civic education should be offered" and "a perception of homeland should be created". Teachers suggested that efforts should be made to "improve peer relationships" for refugee students who sometimes have problems with their classmates. In this regard, three sub-themes were obtained which are improving relationships with friends, providing peer support and providing adaptation training to students within the scope of social studies. Carrying out "academic studies" was proposed for Syrian students in a different theme. This theme contained four sub-themes including enriching the educational process, rendering books more activity-based, starting the students from one grade lower and bringing those kids to the forefront. The most emphasized sub-theme was the enrichment of the educational process. Therefore, it is understood that there are some problems arising from the insufficiency of the teaching materials that they do not address the refugee students. This result points to similar problems addressed by some other studies (Biçer and Kılıç, 2017; Erdem, 2017; Şahin and Doğan, 2018). The last of the suggestions for the Syrian students, who and whose families are affected negatively both materially and spiritually, is "providing social support for the Syrian students". Under this theme, teachers recommended all the citizens, with educators in particular, provide "social support" to families, "empathize with them", and be "patient". Based on these results, the following recommendations can be made:

- It is recommended that students be offered language education at the school they are enrolled in order to ensure a smoother integration.

- It is recommended that language education be accompanied by efforts promoting Turkish culture.

- It is recommended that the refugee students be offered a civic education to help them live in harmony with the society during their stay in the Republic of Turkey.

- It is recommended that teachers enrich the qualifications of the materials they use in the teaching process and improve themselves on teaching methods and techniques.

- Turkish students can be provided with short training to support peer guidance and education.

- For future studies, it is recommended that researchers use quantitative, qualitative and observation techniques in combination. 


\section{References}

Adams, L. D. ve Kirova, A. (2006). Global migration and education: schools, children and families. Londra: Routledge.

Aksoy, Z. (2012). Uluslararası göç ve kültürlerarası iletişim. Journal of International Social Research, 5(20), 292-303.

Amaç, Z. ve Yaşar, M. R. (2017). Temporary education centers for Syrian asylum seekers: Opportunities and challenges [Öz]. International Symposium on the Middle East in 500 years from Mercidabık to Present Konferansında sunulan bildiri, Kilis 7 Aralık Üniversitesi, Kilis. Erişim adresi: http://basinyayin.kilis.edu.tr/duyuru dosyalari

Amaç, Z. ve Yaşar, M. R. (2018). İlk ve ortaokullardaki Suriyeli öğrencilerin eğitimi: Türkiye'de yapılan akademik çalışmalar üzerine sistematik bir inceleme. The Journal of Academic Social Science, 85, 417434.

Arnot, M., Pinson, H. ve Candappa, M. (2009). Compassion, caring and justice: teachers' strategies to maintain moral integrity in the face of national hostility to the "non-citizen". Educational Review, 61(3), 249264.

Biçer, N. ve Kılıç, B. S. (2017). Suriyeli öğrencilere Türkçe öğretmek için kullanılan ders kitaplarının öğretmen görüşleri doğrultusunda değerlendirilmesi. Ana Dili Eğitimi Dergisi, 5(4), 649-663.

Boyden, J., Berry, J. Feeny, T. ve Hart, J. (2002). Children affected by armed conflict in South Asia: A review of trends and issues identified through secondary research. Unicef Regional Office of South Asia.

Bulut, S., Kanat Sosyal, Ö. ve Gülçiçek, D. (2018). Suriyeli Öğrencilerin Türkçe Öğretmeni Olmak: Suriyeli Öğrencilerin Eğitiminde Karşılaşılan Sorunlar. Uluslararası Türkçe Edebiyat Kültür Ĕgitim Dergisi, 7(2), 1210-1238.

Crépeau, F. (2013). The rights of all children in the context of international migration, International Organization for Migration (IOM). http://publications.iom.int/system/files/pdf/children on the move 15may.pdf Erişim tarihi: 20.03.2019.

Creswell, J. W. (2015). Nitel araştırma ve değerlendirme yöntemleri (M. Bütün ve S. B. Demir, Çev.) Ankara: Siyasal kitabevi.

Creswell, J. W., Hanson, W. E., Clark-Plano, V. L.ve Morales, A. (2007). Qualitative research designs: Selection and implementation. The counseling psychologist, 35(2), 236-264.

ÇOÇA (2015). Suriyeli çocukların Türkiye devlet okullarındaki durumu: politika ve uygulama önerileri. İstanbul Bilgi Üniversitesi Çocuk Çalışmaları Birimi. Erişim adresi: http://cocuk.bilgi.edu.tr/wp-content/uploads/2015/09/Suriyeli-Cocuklar-Egitim-SistemiPolitika-Notu.pdf

Emin, M. N. (2016). Türkiye'deki Suriyeli çocukların eğitimi: Temel eğitim politikaları. (Analiz, Sayı: 153) Siyaset, Ekonomi ve Toplum Araştırmaları Vakfı (SETA). İstanbul: Turkuvaz Matbaacılık Yayıncılık A. Ş.

Erdem, C. (2017). Sınıfında Mülteci Öğrenci Bulunan Sınıf Öğretmenlerinin Yaşadıkları Öğretimsel Sorunlar ve Çözüme Dair Önerileri. Medeniyet Eğitim Araştırmaları Dergisi, 1(1), 26-42.

Frater-Mathieson, K. (2004) Refugee trauma, loss and grief, in: R. H. ve D. Moore (Ed.) Educational Interventions for Refugee Children (ss. 12-31). London: Routledge Falmer. 
Gün, M. ve Baldık, Y. (2017). Türkiye'de Kamp Dışında Misafir Edilen Suriyeli Sığınmacı Gençlere Yönelik Eğitim Hizmetleri (Kayserı Örneği). Route Educational and Social Science Journal, 4(2), 287-299.

Holloway, S. ve Valentine, G. (2000). Sociology and the new social studies of childhood. Sociology, $34,770-771$.

Human Rights Watch. (2015). "Geleceğimi Hayal Etmeye Çalıștığımda Hiçbir Şey Göremiyorum” Türkiye'deki Suriyeli Mülteci Çocukların Eğitime Erişiminin Önündeki Engeller - Kayıp Nesil Olmalarını Önlemek, https://www.hrw.org/tr/report/2015/11/09/283247 Erişim Tarihi: 18.03.2019.

İçişleri Bakanlığı Göç İdaresi Genel Müdürlüğü (2013) Yabancılar ve uluslararası koruma kanunu. http://www.goc.gov.tr/files/files/goc kanun.pdf Erişim tarihi: 20. 03. 2019.

İlgar, Ş., Doğan, H. ve Yıldırım, E. (2017). Suriyeli Üniversite Öğrencilerinin Eğitim ve Uyum Sorunlarına İlişskin Genel Yaklaşımları (Kilis 7 Aralık üniversitesi Örneği). Researcher: Social Science Studıes (RSSS), 5(2), 378-394.

Kağnıcl, D. Y. (2017). Suriyeli mülteci çocukların kültürel uyum sürecinde okul psikolojik danışmanlarına düşen rol ve sorumluluklar. Illköğretim Online, 16(4), 1768-1776.

Kaya, İ. ve Yılmaz Eren, E. (2015). Türkiye'deki Suriyelilerin Hukuki Durumu: Arada Kalanların Hakları ve Yükümlülükleri. SETA, Siyaset, Ekonomi ve Toplum Araştırmaları Vakfı, İstanbul. Erişim adresi: http://file.setav.org/Files/Pdf/20151230134459

Keskinkılıç Kara, S. B. ve Şentürk Tüysüzer, B. (2017). Sığınmacı öğrencilerin eğaitimi sürecinde yaşanan sorunlara ilişkin yönetici, öğretmen ve veli görüşleri. Akademik Sosyal Araştırma Dergisi, 6(44), 236250.

Kihtir, A. (2003). Avrupa Birliği'nin eğitim politikası (Yayınlanmamış doktora tezi). İstanbul Üniversitesi, İstanbul.

Kiremit, R.F., Akpınar, Ü. ve Tüfekçi Akcan, A. (2018). Suriyeli öğrencilerin okula uyumları hakkında öğretmen görüşleri. Kastamonu Eğitim Dergisi, 26(6), 2139-2149.

MEB, (2018). Sosyal Bilgiler Öğretim Programı. (http://mufredat.meb.gov.tr/Dosyalar/201812103847686SOSYAL\%20B\%C4\%BOLG\%C4 \%B0LER\%20\%C3\%96\%C4\%9ERET\%C4\%B0M\%20PROGRAMI\%20.pdf). Erişim Tarihi: 05.03. 2019.

Merriam, S. B. (2015). Nitel araştırma: desen ve uygulama için bir rehber. S. Turan (Çev.) Ankara: Nobel yayıncılık.

Miles, B. M. ve Huberman A. M. (2015). Nitel veri analizi. S. Akbaba Altun ve A. Ersoy, (Çev.) 2. Baskı Ankara: Pegem Akademi.

Miller, J. (2009). Teaching refugee learners with interrupted education in science: vocabulary, literacy and pedagogy. International Journal of Science Education. 31(4), 571-592.

Milli Eğitim Bakanlığı. (2017). Sınıfında Yabancı Uyruklu Öğrenci Bulunan Öğretmenler İçin El Kitabı. S. Aktekin (Ed.). Ankara: MEB Yayınları.

Özer, Y. Y., Komsuoğlu, A. ve Ateşok, Z. Ö. (2016). Türkiye'deki Suriyeli Çocukların Eğitimi: Sorunlar ve Çözüm Önerileri, Akademik Sosyal Araştırmalar Dergisi, 4(37), 76-110.

Özkarslı, F. (2014). Suriye'den Türkiye'ye göç ve Suriyelilerin enformel istihdamı. Yayınlanmamış yüksek lisans tezi. Artuklu Üniversitesi Sosyal Bilimler Enstitüsü, Mardin.

Patton, M. Q. (2014). Nitel araştırma ve değerlendirme yöntemleri M. Bütün ve S. B. Demir (Çev.) Ankara: Pegem Akademi. 
Rah, Y., Choi, S. ve Nguyen, T. S. T. (2009). Building bridges between refugee parents and schools. International Journal of Leadership in Education. 12(4), 347-365.

Rossi, A. (2008). The impact of migration on children in developing countries. Youth migration conference. Bellagio: İtalya.Erişim adresi: https://globalnetwork.princeton.edu/bellagio/Rossi.pdf

Saracaloğlu, C. (2014). Göçün eğitime ve eğitim yönetimine etkileri (Turgutlu örneği). Yayınlanmamış yüksek lisans tezi. Okan Üniversitesi, İstanbul.

Sarıtaş, E., Şahin, Ü. ve Çatalbaş, G. (2016). İlkokullarda yabancı uyruklu öğrencilerle karşılaşılan sorunlar. Pamukkale Üniversitesi Sosyal Bilimler Dergisi, 25(1), 208-229.

Söhn, J. ve Özcan, V. (2006). The educational attainment of Turkish migrants in Germany. Turkish Studies, 7(1), 101-124.

Szente, J., Hoot, J. ve Taylor, D. (2006). Responding to speacial needs of refugee children: Practical ideas for teachers. Early Childhood Education Journal, 34(1), 15-20.

Şahin, M., ve Doğan, Y. (2018). Suriyeli öğrencilerin bulunduğu sınıflarda Fen Bilimleri öğretiminde karşılaşılan sorunlar: Nitel bir çalıșma. Uluslararası Eğitim Araștırmacıları Dergisi, 1(1), 13-33.

Şeker, B. D. ve Aslan Z. (2017). Eğitim sürecinde mülteci çocuklar: sosyopsikolojik bir değerlendirme. Kuramsal Eğitim Bilimi Dergisi, 8(1), 86-105.

T.C. İçişleri Bakanlığı, Göç İdaresi Genel Müdürlüğü (GİGM). (2019). Yıllara göre geçici koruma kapsamindaki Suriyeliler. http://www.goc.gov.tr/icerik3/gecici-koruma 3633784713 Erişim tarihi: 26.10 .2019

Topkaya, Y. ve Akdağ, H. (2016). Sosyal Bilgiler Öğretmen Adaylarının Suriyeli Sı̆̆ınmacılar Hakkındaki Görüşleri (Kilis 7 Aralık Üniversitesi Örneği). Çankırı Karatekin Üniversitesi Sosyal Bilimler Enstitüsü Dergisi, 7(1), 767-786.

Unicef Araştırma Ofisi. (2019). http://www.unicef-irc.org/knowledge-pages/Migration-andchildren/.(Erişim Tarihi: 18.03.2019).

URL-1: T.C. Kültür ve Turizm Bakanlığı. (2019). Kültür Nedir? http://www.kultur.gov.tr/TR96255/turk-kulturu.html Erişim tarihi: 01.04.2019.

Yaşar, M. R. ve Amaç, Z. (2018). Teaching Syrian students in Turkish schools: Experiences of teachers. Sustainable Multilingualism, 13, 232-244.

Yıldırım, A. ve Şimşek, H. (2013). Nitel Araştırma Yöntemleri. Ankara: Seçkin Yayıncılık. 